\title{
Almaleea, a new genus of Fabaceae from south-eastern Australia
}

\author{
Michael D. Crisp and Peter H. Weston
}

\begin{abstract}
Crisp, Michael D. ${ }^{1}$ and Weston, Peter $H^{2}{ }^{2}$ ( Division of Botany and Zoology, Australian National University, GPO Box 4, Canberra ACT 2601, formerly Australian National Botanic Gardens, GPO Box 1777, Canberra ACT 2601 Australia; ${ }^{2}$ National Herbarium of New South Wales, Royal Botanic Gardens, Sydney NSW 2000 Australia) 1991. Almaleea, a new genus of Fabaceae from south-eastern Australia. Telopea 4(2): 307-311. The new genus described herein was identified in an earlier cladistic analysis of genera in the tribe Mirbelieae. It includes species formerly placed in Pultenaea and Dillwynia, and is closely related to Dillwynia and Eutaxia. Combinations are made for the five known species, which occur in Tasmania, Victoria and eastern New South Wales. A fuller account of the species will appear in the Flora of New South Wales.
\end{abstract}

\section{Introduction}

The genus described here includes species formerly placed in Pultenaea and Dillwynia. Thompson (1961) placed these in a subgroup of Pultenaea distinguished by minute stipules and hooked styles. Crisp and Weston (1987) included these species (as the 'Pultenaea incurvata group', separated from Pultenaea sensu stricto) in a cladistic analysis of genera in the tribe Mirbelieae. Their results showed that Almaleea is more closely related to Dillwynia than to Pultenaea. It was included in a clade with Eutaxia, Dillwynia, Latrobea and Pultenaea neurocalyx (the last also analysed separately from Pultenaea). Synapomorphies for this clade were: wings longer than the keel and a hooked style (both reversed in Latrobea). Almaleea was placed as sister-group to the other four taxa. Subsequently, one of us has re-analysed Pultenaea and closely related genera (MC, unpublished), using additional characters and including Pultenaea selaginoides, a taxon that was omitted from our earlier analysis. Using successive weighting, a single most parsimonious cladogram was produced that included the following clade (internal relationships indicated by parentheses): Latrobea, (Pultenaea selaginoides, ((Almaleea, Dillwynia), (Eutaxia, Pultenaea neurocalyx))). This clade is united by two characters: leaves concave or paler adaxially, and leaves more or less keeled abaxially. Eutaxia, Dillwynia, Pultenaea neurocalyx and Almaleea form a clade united by the wings being shorter than the keel. Because it was structurally correlated with the short keel, the hooked style character was excluded from this analysis.

All five taxa can be readily diagnosed by autapomorphies (uniquely derived characters shared by their species). Latrobea has a calyx with equal lobes and the standard is peaked. Pultenaea selaginoides has caducous, scale-like bracts. Almaleea has distinctive bracts forming an involucre at the base of the inflorescence. Dillwynia is distinguished by its subterete (often triquetrous) leaves with an adaxial groove, its standardlamina, which is broader than long and reniform or bilobed, and its wing apices, which are enlarged and downcurved. Eutaxia has decussate leaves. Pultenaea neurocalyx has ciliate leaf margins. 
Besides lacking the characters which define the above clade, Pultenaea differs from all the taxa in it, including Almaleea, in having unique, conspicuous stipules which have scarious margins and which are united behind the petiole.

This brief account of Almaleea is needed to provide names for the Flora of New South Wales. We intend to publish a full treatment of the genus in the near future.

The following key distinguishes all the genera listed in the 'Pultenaea group' by Crisp and Weston (1987: Table 8), except that the 'genus aff. Aotus' also includes the Oxylobium microphyllum group and Pultenaea selaginoides has been separated from Pultenaea as a result of the more recent cladistic analysis.

\section{Key to Genera Related to Pultenaea}

1 Stipules conspicuous, united behind the petiole, margins scarious Pultenaea

$1^{*}$ Stipules minute, free, without scarious margins

2 Bracteoles absent; leaves in whorls of 3 or more, often irregularly .. Aotus

2* Bracteoles present; leaves spirally arranged or decussate

3 Leaves concave or paler on the adaxial (upper) surface, or terete to triquetrous and longitudinally grooved above

4 Leaves 3-nerved on abaxial (lower) surface; calyx with 5 or 10 ribs

5 Leaves decussate, lacking ciliate margins; calyx not prominently ribbed

Eutaxia

$5^{*}$ Leaves arranged spirally, margins ciliate; calyx prominently ribbed

$4^{*}$ Leaves not 3-nerved abaxially; calyx not ribbed

Pultenaea neurocalyx

6 Calyx with uniform teeth or lobes; standard peaked; pod compressed, triangular; aril neither channelled longitudinally nor papillate

Latrobea

$6^{*}$ Calyx with upper two lobes broader and united higher than lower three; standard rounded or emarginate at apex; pod turgid, more or less ovoid; aril channelled longitudinally and papillate

7 Inflorescence an anauxotelic head surrounded by an involucre of leaves progressively modified into bracts by enlargement of the stipular base; bracts persistent

Almaleea

$7^{*}$ Inflorescence various; if head-like, then lacking an involucre; bracts usually deciduous

8 Style abruptly hooked upwards at the tip; wing petals distinctly longer than keel; standard-lamina reniform or bilobed; leaves terete or triquetrous with a longitudinal adaxial groove (except $D$. ramosissima may be broadly channelled adaxially) ... Dillwynia

$8^{*}$ Style gently curved; wing petals equal to or slightly longer than keel; standard-lamina \pm orbicular; leaves concave, not terete or triqetrous

Pultenaea selaginoides

$3^{*}$ Leaves with recurved margins, or if flat then darker on the adaxial surface

9 Leaves flat; style longitudinally winged

Urodon

9* Leaves with recurved to revolute margins; style not winged

10 Calyx with upper two lobes enlarged and rounded, lower three lobes vestigial; hairs peltate Euchilopsis

$10^{*}$ Calyx not as above; hairs not peltate 
11 Keel beaked, lobed on the upper margin only; pod glabrous inside Phyllota

$11^{*}$ Keel rounded at apex, lobed asymmetrically on both upper and lower margins; pod pubescent inside

Genus aff. Aotus

Almaleea Crisp \& P. Weston, gen. nov.

Frutices exiles, paludes incolentes; foliis alternis, simplicibus, superne concavis, inferne plerumque lineam rubiginosam vel badiam instructis; stipulis minutis liberis; floribus in capitulum terminale aggregatis, foliorum basibus in bracteas saepe trilobas successive amplificatis involucro cinctis; bracteis fructu persistentibus; bracteolis in pedicello affixis; floribus papilionaceis, vexillo longiore quam latiore, aliis quam carina longioribus; staminibus liberis; ovario pubescenti, stylo compresso apice uncinato, stigmate terminali capitato, ovulis 2; legumine turgido ovoideo; semino triangulari, testa laevi, arillo papillato longitudinaliter canaliculato.

TYPE: Almaleea incurvata (Cunn.) Crisp \& P. Weston

Erect to procumbent shrubs or subshrubs. Leaves arranged spirally, simple, margins entire, upper surface flat or concave, lower surface usually with a dull reddish or brownish central streak; stipules minute, free; petiole very short, pulvinate. Inflorescence a terminal head surrounded by an involucre of leaves with stipular bases progressively enlarged into bracts; outer bracts often 3-lobed with modified lamina and stipules; bracts persistent in fruit; bracteoles entire, linear, attached to the pedicel. Corolla orange-yellow with reddish markings; standard longer than lower petals, slightly longer than wide; wing petals longer than keel. Stamens free. Ovary hairy to base; style compressed and hooked at apex; stigma terminal, capitate; ovules 2, on short funicles. Pod turgid, more or less ovoid; seeds triangular, smooth with papillose aril.

5 species in freshwater bogs along the east coast of Australia from far north-eastern New South Wales to Tasmania.

Eтymology: We have named this genus in honour of the late Mrs Alma Lee (née Melvaine), a botanist with a long and distinguished career at the National Herbarium of New South Wales. We wish to highlight her contributions to systematics of the Fabaceae, especially her critical insights into relationships in the tribe Bossiaeeae.

\section{Key to Species}

1 Standard c. $6 \mathrm{~mm}$ long; leaf-margins flat, tuberculate, ciliate when immature

1* Standard $>6 \mathrm{~mm}$ long. leaf-margins slightly incurved to involute smooth and glabrous or whole abaxial leaf surface tuberculate and sparsely pubescent when immature

2 Branchlets moderately to densely covered with antrorse to spreading hairs; bracteoles 3-5 mm long; leaves towards end of stems with incurved apices

A. incurvata

2* Branchlets glabrous to densely covered with appressed to antrorse hairs; bracteoles 1-2.5 mm long; leaves not incurved

3 Leaves glabrous or rarely pubescent when young, not tuberculate, with flat to slightly incurved or rarely involute margins; lower part of calyxtube glabrous or nearly so; outer bracts broad-ovate to orbicular 
$3^{*}$ Leaves usually pubescent abaxially when young, usually tuberculate abaxially, with moderately incurved to involute margins; lower part of calyx tube hairy; outer bracts narrow-ovate to ovate

4 Calyx tube sparsely pubescent and lobes moderately so (calyx epidermis clearly visible beneath)

A. capitata

$4^{*}$ Calyx densely villous (calyx epidermis scarcely visible beneath)

A. cambagei

Almaleea paludosa ( $J$. Thompson) Crisp \& P. Weston, comb. nov.

Basronym: Pultenaea paludosa J. Thompson, Proc. Linn. Soc. New South Wales 83: 188 (1958).

Holotype: New South Wales: Swamps between Coogee and Bondi, E. Betche, 16 September 1886 (NSW 38185, photo CBG).

Distribution: Coast from the Grafton district, North Coast of New South Wales, to eastern Gippsland, Victoria.

Almaleea incurvata (Cunn.) Crisp \& P. Weston, comb. nov.

BAsionym: Pultenaea incurvata Cunn. in Field, Geogr. Mem. : 346 (1825).

TYPe CitATIOn: 'Margins of peaty bogs. Kings Table Land'. Lectotype (here designated): New Soutr Wales: Peaty bogs, Kings Tableland, A. Clunningham] (K: Herbarium Hookerianum, 1867, 'negative no. Kew 1039'). IsoLECTOTYPEs: BM, CGE (2 sheets), K (2 sheets), W. Photos CBG.

Distribution: Blue Mountains, near Sydney, New South Wales.

Almaleea subumbellata (Hook.) Crisp \& P. Weston, comb. nov.

BAsIONYM: Pultenaea subumbellata Hook., Bot. Mag. 60: t. 3254 (1833).

Type CitAtion: '...Glasgow Botanic Garden is indebted to Dr. Scott, who sent seeds from Van Diemen's Land, from which plants were raised that blossomed in April, 1833'. Lectotype (here chosen): plate 3254 (no specimen is extant).

Synonym: Pultenaea subumbellata var. alpina Hook. f., Fl. Tasmaniae 1: 87 (1856).

Type Citation: 'Gunn 319. On the Western and other mountains, ascending to 4000 feet...'. SYNTYPES: Tasmania: K (2 sheets with several specimens from Herbarium Hookerianum, annotated in pencil: ' $P$ subumbellata Hook. var. beta'). IsOSYNTYPES: BM, CGE (2 sheets), K (1 sheet), NY. Photos CBG.

Distribution: Mostly in mountainous regions, up to $1500 \mathrm{~m}$ altitude, in Tasmania, Victoria east from the Grampians Ranges and Portland district, and Southern Tablelands of New South Wales south from Big Badja Mountain.

Notes: This is a variable species, and one variety has been described, from subalpine altitudes. Further investigation is needed to determine whether infraspecific taxa should be recognised.

Almaleea capitata (J.H. Willis) Crisp \& P. Weston, comb. nov.

BASIONYM: Dillwynia capitata J.H. Willis, Victorian Naturalist 73: 192 (1957).

Holotype: North-EAST Victoria: near Clover Dam, between Tawonga and Bogong townships, at Cranky Charlie's Turntable on the SEC mountain road, J. Galbraith, 4 November 1949 (MEL 627545). Photo CBG. IsOTYPE: NSW (2 sheets). 
SYNONYM: Dillwynia capitata var. uliginosa J.H. Willis, Muelleria 1: 124 (1967).

Holotype: Victoria: On boggy ground at c. 3600 feet $[1080 \mathrm{~m}]$, near Black Mountain Station, Wulgulmerang, far eastern Victoria, K.C. Rogers, 9 December 1962 (MEL 627543, partly). IsOTYPES: MEL 627543 (partly), MEL 627544, Photos CBG, NSW.

Distribution: Subalpine areas in the Southern Tablelands of New South Wales, south from Namadgi National Park and the eastern highlands of Victoria east from the Wonnangatta Valley.

NoTes: The identity of this taxon has been problematic, owing to the poor quality of the type material. Despite several searches at the type locality, nobody, including the original collector and one of us (MC), has been able to re-locate it there. However, other populations closely resembling the holotype have been found in the same region, e.g. in the Wonnangatta Valley (E. Chesterfield 2587, CBG, MEL) and at Rocky Plains near Mt Wombargo (M. Crisp 8092a-g, CBG, NSW, MEL).

When J.H. Willis described Dillwynia capitata var. uliginosa, only three specimens of $A$. capitata had been collected. Subsequent collections indicate that the types of the varieties represented the extremes of variation in leaf length and that the varieties are not distinct taxa.

Almaleea cambagei (Maiden \& Betche) Crisp \& P. Weston, comb. nov.

Basionym: Pultenaea cambagei Maiden \& Betche, Proc. Linn. Soc. New South Wales 33: 308 (1908).

Type Citation: 'Torrington, Deepwater, Nova Anglica (in paludibus, R.H. Cambage; September mensis MDCCCCVII)'. LeCTOTYPE (here designated): New SOUtH WALES: In swamps or damp flats, Torrington, R. H. Cambage 1621A, 29 September 1907 (NSW 38177). Isolectotypes: BM, K, MEL. Photos CBG.

SYNONYM: Pultenaea subumbellata var. cambagei H. Williamson, Proc. Roy. Soc. Victoria 33: 145 (1921).

Distribution: Northern Tablelands of New South Wales in the Torrington area and also in the headwaters of the Henry River.

\section{Acknowledgements}

We thank Evan Chesterfield for collecting A. capitat from the Wonnangatta Valley; Joan Taylor and Ian Telford for assistance; and the heads of the HO and MEL herbaria for the loan of specimens.

\section{References}

Crisp, M.D. and Weston, P.H. (1987). Cladistics and legume systematics with an analysis of the Bossiaeeae, Brongniartieae and Mirbelieae. In C.H. Stirton (ed.), Advances in Legume Systematics, part 3: 65-130. (Royal Botanic Gardens, Kew).

Thompson, J. (1961). Papilionaceae. Contributions from the New South Wales National Herbarium. Flora Series 101(1): 1-91. 